\title{
The Representation of Muslim Characters in Post 9/11 Fiction
}

\author{
Sara ABDERRAZAG \\ Department of English Language and Literature \\ Faculty of Letters and Languages, University of Mustapha Stambouli \\ Mascara, Algeria \\ Ilhem SERIR \\ Department of English \\ Faculty of Letters and Languages, University of Tlemcen \\ Tlemcen, Algeria
}

\begin{abstract}
In the wake of September $11^{\text {th }}$, attacks, several writers seek to depict the event's impact on the country and its population. However, at the very beginning novelists seem to support the victimization of Americans and accuse the Muslims but later, many voices, including Muslim as well as non-Muslim writers, contribute through giving a voice to the 'enemy', and the American novelist Jess Walter is no exception. This analytical study, then, aims at providing evidence that Walter portrays Muslim characters in his work The Zero (2006) and that he does so to deconstruct the idea that Americans are totally innocent and victims while Muslims are the only entity to blame. The present paper, thus, is an attempt to pinpoint that through depicting several characters, including American and Middle Eastern ones, as reacting to the dominating 'truth', Walter seems to be giving a voice to the voiceless and providing readers with a different version of reality. Therefore, the ultimate purpose of this study is to prove that The Zero can be considered as a counter-discourse.
\end{abstract}

Keywords: discourse, Muslim characters, reality, Jess Walter, 9/11 fiction

Cites as: ABDERRAZAG, S, , \& SERIR, I. (2019). The Representation of Muslim Characters in Post 9/11 Fiction. Arab World English Journal for Translation \& Literary Studies, 3 (1) 100-112. DOI: http://dx.doi.org/10.24093/awejtls/vol3no1.8 